Historic, archived document

Do not assume content reflects current scientific knowledge, policies, or practices. 

62.55

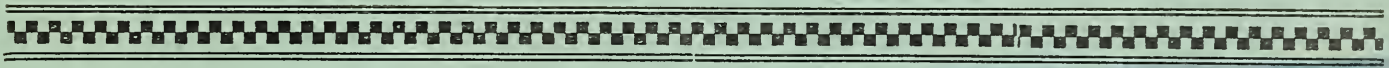

\section{PRICE LIST}

FALL 1925-SPRING 1926

\section{FOREST NURSERIES

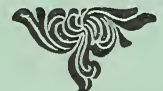

TREES FOR FOREST PLANTING

Nurseries at Edgewood

CHARLES GALE SHEDD, President ORVILlE E. CAIN, Treasurer

ALBERT K. PROELL, Forester

Telephone: 1365

All our Stock is Carefully Inspected, both by State and Federal Officials and a Certificate Showing that our Trees are Free from Insects or Disease goes with every Shipment.

ADDRESS ALL CORRESPONDENCE TO THE ASSOCIATION

TO INSURE PROMPT ATTENTION.

\section{KEENE FORESTRY ASSOCIATION}

IEENE, NEW HAMPSHIRE 


\title{
NURSERY STOCK PRICE LIST
}

\author{
PRICES NET F. O. B. KEENE \\ BOXES CHARGED FOR AT COST
}

BILLS PAYABLE WITHIN 30 DAYS

Cash with order or satisfactory references required from parties unknown to us.

All goods are at purchasers risk after they are delivered to the forwarding companies and we receive their receipt for the shipment in good condition. Claims for damage while in transit must be made to the delivering company.

Seedlings and 3-year transplants will be sold only in lots of 100 or multiples thereof. 500 trees at 1000 rate.

WE PLANT OUR TREES AT COST OR BY CONTRACT

\section{PINUS STROBUS, WHITE PINE}

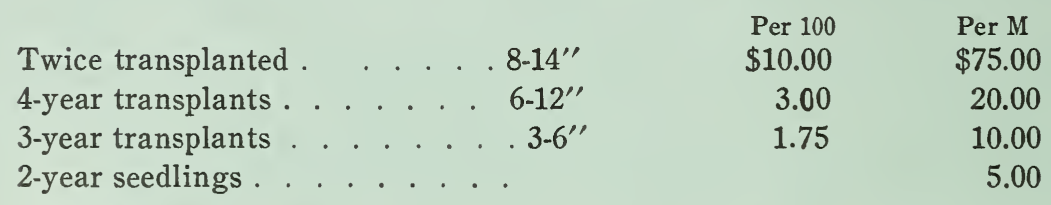

For extensive forest planting use our 3-year or 4-year old transplants.

PINUS RESINOSA, RED PINE

Several times transplanted . . $7-9 \mathrm{ft}$. $\$ 250.00$

2-year seedlings . . . . . $\quad 1.00 \quad \$ 8.00$

PINUS AUSTRIACA, AUSTRIAN PINE

3-year transplants . . . . . 3-5" $\$ 3.00 \quad \$ 20.00$

PINUS SYLVESTRIS, SCOTCH PINE

3-year transplants . . . . . 4-8" $\$ 1.75$

2-year seedlings . . . . . . 5.00

PINUS MUGHO, HUGHO PINE

2-year seedlings . . . . . . . $\quad \$ 3.00 \quad \$ 20.00$

PICEA ALBA, WHITE SPRUCE

3-year transplants . . . . . 3-5" $\$ 2.00$

3-year seedlings . . . . . . . 1.00 
PICEA EXCELSA, NORWAY SPRUCE

\begin{tabular}{|c|c|c|c|}
\hline & & Per 100 & Per $\mathbf{M}$ \\
\hline Twice transplanted & . . . . . 7-12" & $\$ 10.00$ & $\$ 75.00$ \\
\hline Twice transplanted & . . . . . . 5-8" & 8.00 & 50.00 \\
\hline 5-year transplants & . . . . . $7-12^{\prime \prime}$ & 5.00 & 35.00 \\
\hline 4-year transplants & . . . . . . 5-9" & 3.00 & 20.00 \\
\hline 3-year transplants & . . 3-6" & 2.00 & 12.00 \\
\hline 3-year seedlings . & $\cdot \cdot \cdot \cdot \cdot \cdot \cdot$ & & 8.00 \\
\hline 2-year seedlings & . . . . . . & & 5.00 \\
\hline
\end{tabular}

PICEA PUNGENS, COLORADO BLUE SPRUCE

Four times transplanted . . . 16-24"

Three times transplanted . . 10-16"

$\$ 150.00$

75.00

Twice transplanted. . . . . 6.10" 25.00

3-year transplants . . . . . . 3-5" 5.00

2-year seedlings . . . . . . 2.00

15.00

PSEUDOTSUGA TAXIFOLIA, DOUGLAS FIR

3-year transplants . . . . . 3-6"

$\$ 3.00$

$\$ 20.00$

2-year seedlings

\section{THUYA OCCIDENTALIS, AMERICAN ARBORVITAE}

3-year transplants . . . . . 3-6" $\quad \$ 5.00 \quad \$ 35.00$

2-year seedlings . . . . . . $2.00 \quad 15.00$

THUYA ORIENTALIS, ORIENTAL ARBORVITAE

2-year seedlings . . . . . . $\$ 5.00$

$\$ 40.00$

TSUGA CANADENSIS, HEMLOCK

Once transplanted . . . . . 3-5" $\$ 10.00$

$\$ 75.00$

ABIES BALSAMEA, BALSAM FIR

3-year transplants . . . . . . 3-5"

$\$ 5.00$

2-year seedlings . . . . . . 2-4"

2.00

$\$ 35.00$

15.00

ABIES CONCOLOR, CONCOLOR FIR

2-year seedlings . . . . . $\$ 8.00$

$\$ 50.00$

LARIX EUROPEA, EUROPEAN LARCH

2-year seedlings . . . . . . .

$\$ 2.00$

$\$ 15.00$

For Christmas tree planting use Spruce, Douglas Fir or Balsam Fir. 


\section{INSTRUCTIONS}

\section{CARE OF 'TREES UPON ARRIVAL}

The trees should be taken out of the boxes as soon as possible upon arrival. The bundles should be untied and the trees "heeled in." This is done by digging a shallow trench from five to six inches deep, depending upon the size of the trees, and placing the trees therein at an angle of about 40 degrees, leaning the tops of the trees towards the sun. They should be spread out rather thinly. The trees should then be covered over with moist earth up to within two or three inches of the top. It is well to heel the plants in a cool and shady spot in moist earth. It is also advisable to water them somewhat, but care should be taken that they are not watered too heavily, for if they are they may heat. In this way they will keep several days, but it is always best to plant the small trees as soon as possible after their arrival.

\section{TIME FOR PLANTING}

The best time for planting coniferous trees is in the spring as soon as the snow is gone and the frost is out of the ground, or in the fall during the latter part of July and in the months of August and September. Weather conditions, however, should have more or less bearing upon fall planting. If the season has been extremely dry and the ground is in a dried up condition, it is not advisable to plant in the fall. Fall planting is also inadvisable in wet, heavy soil where there is danger of heaving.

\section{DISTANCES USED IN FOREST PLANTING AND THE NUMBER OF TREES TO THE ACRE}

Coniferous trees are usually planted $4 \times 4,5 \times 5$, or $6 \times 6$. The number of plants to the acre at these distances are for $4 \times 4,2,720$ trees; for $5 \times 5,1,740$ trees; for $6 \times 6$ 1,210 trees. It is not advisable to plant coniferous trees further apart than $6 \times 6$, or otherwise they will grow "limby" and not make good timber.

Where there is a market for Christmas trees it would be advisable to plant Spruce or Balsam amongst the Pine If the Pine are planted six feet apart, the Spruce can be planted between, spacing the trees three feet apart, alternating Pine and Spruce.

In six or seven years the Spruce can be cut out and sold for Christmas trees. The income derived from the sale of these trees will pay for the planting of both the Spruce and Pine, plus an annual interest of at least $6 \%$ on the money invested, so that in seven years time the original cost of planting would be eliminated entirely.

It would be advisable to use Norway Spruce wherever feasible, as this tree makes an excellent Christmas tree, bringing a good price in the market.

\section{METHODS USED IN PLANTING}

In planting small tracts two men can work to the best advantage. One man with a grubbing hoe makes the holes, the other man follows and plants the trees. The roots of the trees should be submerged in a thick puddle of mud, and the trees should be always carried in a pail, submerged in the mud until planted. It is very important that the roots of the small trees do not get dry, as they are certain to be killed if they do. It is always well to set the plants somewhat deeper than they originally stood in the nursery to allow for settling. Great care should be taken that the plants are set firmly in the ground. They cannot be planted too firmly. In planting more extensively, a gang of five men will work to the best advantage. Two men go ahead in a parallel line, making the holes, one man follows them with a pail with the trees, and he hands the small trees to the two men coming behind, who plant them. It is not necessary to prepare the ground in any way before planting. 